\title{
Instrinsic Religiosity mempengaruhi Niat Beli Produk Halal
}

\section{Intrinsic religiosity affects intention to purchase halal products}

\section{Yudha Trishananto}

Fakultas Ekonomi dan Bisnis Islam, Institut Agama Islam Negeri Salatiga

E-mail: yudhatrishananto@iainsalatiga.ac.id

\section{Zabrina Chandra Devi}

Fakultas Ekonomi dan Bisnis Islam, Institut Agama Islam Negeri Salatiga E-mail: zabrinadevi@gmail.com

\begin{abstract}
This study aims to determine the effect of Intrinsic Religiosity, Knowledge of Halal Products on Intention to Purchase Halal Products with Halal Product Awareness as a mediating variable. The technique used is purposive sampling technique. The results showed that the intrinsic religiosity variable bad a significant effect on the intention to buy balal products, the intrinsic religiosity variable and knowledge of halal products had a significant effect on halal product awareness. The variable knowledge of halal products is not significant to the variable of purchase intention of halal products. Halal product awareness mediates intrinsic religiosity and knowledge of halal products on the purchase intention of halal products produk.
\end{abstract}

Keywords: intrinsic religiosity, knowledge, halal product awareness, purchase intention

\section{Pendahuluan}

Kemajuan dibidang teknologi semakin meningkat dan berkembang khususnya di Indonesia. Indonesia juga tercatat sebagai Negara dengan jumlah muslim terbanyak. Dengan jumlah penduduk muslim yang bedar ini, minat terhadap barang-barang halal akan meningkat, sehingga Indonesia harus memperluas produknya agar terjamin kehalalannya. Indonesia sendiri memiliki Badan Pengawas dan Pendistribuan Obat dan Makanan, khususnya Majelis Ulama Indonesia (LPPOMMUI) yang bertugas mengawasi barang-barang yang mengalir secara lokal.. ketentuan label halal tercantum dalam Undang-Undang RI No.33 tahun 2014 tentang Jaminan Produk Halal, di pasal 4 yang menyebutkan bahwa: "Barang yang masuk, mengalir harus halal". barang halal adalah barang yang telah dinyatakan halal menurut hokum Islam. Sejalan engan itu, bisnis makanan saat ini sedang berlom menciptakan produk halal. Hasirnya barang-barang halal tersebut, pelanggan akan merasa yakin dan terlindungi untuk memakan makanan tersebut.

Bisnis makanan saat ini sedang berkembang pesat. Berbagai macam makanan sudah mulai mengalir.. Kemajuan jenis olahan pangan yang ada, umat Islam harus spesifik ketika membeli olahan makanan yang akan dimakan.. Saat ini informasi masyarakat Indonesia atas halalnya suatu barang masih rendah, jadi perlu adanya perhatian masyarakat guna membangun informasi, selanjutnya membangun keyakinan yang tegas dari setiap orang (Muktadir-Al-Mukit \& Keyamoni, 2019). 


\section{Pilihan Tempat Makan oleh Masyarakat Indonesia}

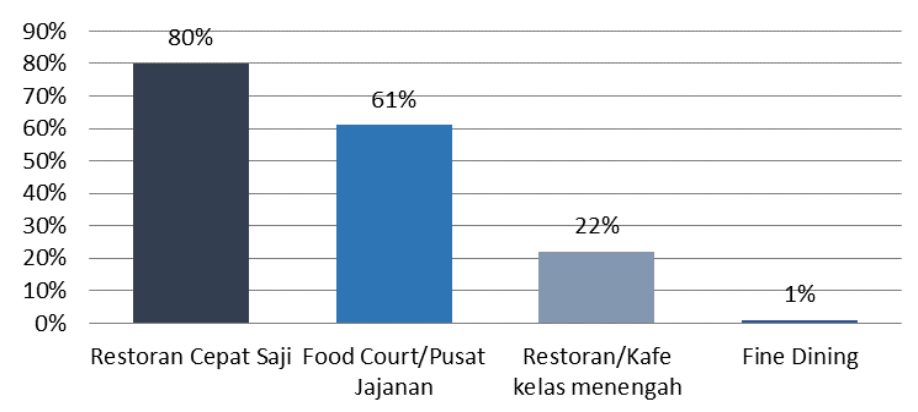

Gambar 1. Grafik Pilihan Tempat Makan Masyarakat Indonesia Sumber : Berita online SWA, January 282016 oleb Sri Niken Handayani

Dalam grafik diatas restoran merupakan tempat makan yang sangat diminati oleh masyarakat Indonesia. Sebanyak $80 \%$ orang memutuskan untuk makan di tempat, pada saat itu $61 \%$ orang memutuskan untuk membeli di food court, 22\% memutuskan untuk pergi ke restoran kelas atas.

Kemajuan tempat makan restoran dapat ditemukan di Salatiga. Dari merek lokal sampe internasional, ini membuat setiap bisnis mengejar pembeli untuk mendapatkan keuntungan. Beberapa gerai saat ini membuat setiap bisnis mengejar pembeli untuk mendapatkan keuntungan. Beberapa gerai drive-through dunia seperti KFC dan sekitarnya seperti Popeye Chicken Express, Oti Fried Chicken, Krezy Chicken, Olive Fried Chicken dan Rocket Chicken telah hadir di Kota Salatiga.

Rocket Chicken yakni tempat makan drive-through yang saat ini cukup dikenal. Saat ini ayam roket banyak dikunjungi masyarakat Salatiga karena siklus penyajiannya yang sangat cepat dan tidak perlu waktu yang lama untuk berhenti. Ayam roket juga punya menu yang bisa dijelajahi pembeli.mAyam roket adalah organisasi yang dipenuhi dengan restoran drive-through, dengan makanan utama, ayam bakar, burger, dan steak dengan harga yang terjangkau

\section{Kajian Pustaka}

\subsection{Religiusitas Intrinsik}

Religiusitas mempengaruhi orang secara tipikal dan intelektual. Religiusitas punyai segmen yang mengasumsikan bagian penting yang sama dalam keberadaan individu yang ketat.. Religiusitas adalah sesuatu yang penting dalam keberadaan manusia. Agama merupakan penanda penting dalam interaksi dinamis yang mengarahkan individu untuk beryindak secara sah dan bermoral. (Hwang, 2015). Aktivitas beragama bukan hanya terjadi ketika seseorang melakukan ibadah, tetapi juga saat melakukan latihan lain. Sulit diidentifikasi dengan latihan dapat dilihat dengan mata, tetapi latihan yang tidak terlihat di hati seseorang. Religiusi bisa dilihat dari latihan-latihan beragama yang diaplikasikan di kehidupan seseorang.

Karakteristik dari orientasi intrinsik adalah bahwa seorang individu melacak alasan mendasar untuk agamanya. Betapapun bisa diharapkan mereka membawa pelajaran agama yang mereka yakini ke dalam perilaku kehidupan sehari-hari di arena publik. Hati dan jiwanya secara konsisten terarah dan terfokus pada agama. (Yousaf \& Malik, 2013). Seseorang yang memiliki arah ketegasan bawaan menunjukkan bahwa karena agama adalah tujuan yang luar biasa, cara pandang dan praktik yang direncanakan akan sesuai dengan pelajaran ketat yang telah diberikan dan memiliki kewajiban tinggi untuk pelajaran penting. 


\subsection{Pengetahuan Produk Halal}

Pengetahuan produk merupakan informasi tentang kualitas, atribut, keunggulan barang serta hasil dan nilai pemenuhan yang diberikan oleh barang tersebut kepada pelanggan. Informasi barang mencakup kualitas barang atau properti, khususnya cara pembuat memberikan nasihat tentang penggunaan atau pemanfaatan barang sehingga kapasitas barang sesuai (Fridayanti, 2016).

Informasi dicirikan sebagai semacam perspektif untuk semua data/berita yang dapat direpresentasikan ke dalam kepribadian pembeli yang pada umumnya setara dengan informasi tentang barang halal. Pembeli yang lebih terpelajar akan lebih masuk akal dalam memilih sesuatu yang sesuai dengan asumsi mereka. Informasi barang mengasumsikan bagian penting dalam perilaku pembeli (Selatan, 2018)

Informasi tentang produk halal yakni seberapa baik seseorang memahami makanan yang sehat, sesuai dan aman (halal) untuk digunakan. Pembeli yang memiliki lebih banyak informasi tentang suatu barang akan berpikir lebih masuk akal saat memilih barang yang akan mereka beli. Dengan asumsi informasi yang dipindahkan, pembeli akan punyai kapasitas yang lebih tinggi untuk memilih suatu barang

\subsection{Kesadaran Produk Halal}

Kesadaran adalah gagasan menyimpulkan pemahaman dan kesan peristiwa atau mata pelajaran. Perhatian terhadap halal dalam arti sebenarnya menyiratkan memiliki pengalaman tentang apa yang terjadi sekarang.(Awan et al., 2015)

Kesadaran halal adalah informasi individu tentang ide halal, siklus halal, dan berpikir tentang melahap makanan halal sangat penting baginya. Kewaspadaan terhadap (perhatian halal) mengandung pengertian mendapatkan apa yang halal dan halal untuk dimakan dan mendapatkan apa yang tidak boleh dibakar sesuai dengan pedoman Islam (Astuty \& Umiyati, 2018).

Dengan kesadaran halal, pembeli dapat memilih barang yang mereka butuhkan tanpa berpikir dua kali, karena mereka pasti tahu dan mengerti bahwa barang yang mereka beli halal. Individu yang memiliki kesadaran halal sebagian besar cenderung memastikan barang yang akan dibeli, bahan-bahan untuk membuat barang dan bahan tambahan yang digunakan adalah halal, dan memiliki informasi yang memadai untuk menentukan pilihan yang tepat sebelum membeli suatu barang

\subsection{Niat Beli}

Tujuan pembelian merupakan salah satu tahapan dalam interaksi dinamis bagi pembeli yang muncul setelah suatu kebutuhan dirasakan oleh orang tersebut. Persyaratan tunggal dapat dianimasikan dari dalam atau dari luar orang tersebut. Tujuan Beli yakni kecenderungan pembeli untuk membeli sesuatu atau melakukan suatu tindakan yang diidentikkan dengan pembelian dan diperkirakan oleh derajat pelanggan dalam melakukan pembelian (Fauzia et al., 2019)

Harapan untuk membeli menyiratkan bahwa pelanggan akan membeli barang itu lagi setelah menilai barang dan menyadari barang tersebut baik jika dibeli. Dengan cara ini, tujuan pembelian pembeli untuk barang halal adalah keinginan pelanggan untuk membeli barang halal (Syafrida \& Hartati, 2019)

\section{Metode Penelitian}

\subsection{Metode, Data dan Variabel}

Penelitian ini menggunakan eksplorasi kuantitatif, karena informasi dalam penelitian ini berupa angka-angka dan penelitian yang menggunakan pengukuran. Informasi ini diperoleh dari jajak pendapat yang disesuaikan dengan responden, yang kemudian disiapkan dan dipecah untuk mendapatkan data logis. 
Faktor bebas adalah variabel yang mempengaruhi atau menyebabkan berubahnya atau berkembangnya variabel terikat. Variabel terikat adalah variabel yang dipengaruhi atau yang merupakan hasil dari variabel otonom

\subsection{Teknik Analisis Data}

Dalam penelitian ini peneliti memanfaatkan informasi penting. Informasi penting adalah informasi yang diperoleh langsung oleh para ahli di lapangan. Bermacam-macam informasi penting diselesaikan dengan menyebarkan survei (jajak pendapat) secara langsung kepada kelompok masyarakat Salatiga sebagai objek penelitian

\section{Hasil dan Pembahasan}

\subsection{Uji Instrumen Penelitian}

\section{Uji Validitas}

Uji ini digunakan untuk mengukur sahnya suatu survei. Uji validitas dikoordinasikan untuk menentukan batas instrumen eksplorasi untuk mengukur apa yang seharusnya dinilai. Pengujian keabsahan instrumen pengujian menggunakan resep terukur koefisien koneksi Pearson, kemudian strategi komputasinya menggunakan program SPSS.

Pengujian validitas harus dapat dilakukan dengan menggunakan 40 responden karena hasil pengujian mendekati tikungan biasa. . Uji yang digunakan pada instrumen dikatakan sah jika $r$ hitung melebihi dari $\mathrm{R} 2=0,361$

Segala hal tentang intrinsic religiosity, informasi tentang barang halal, barang halal dan tujuan pembelian yang dicoba untuk validitas membawa $r$ tabel lebih penting dari $(0,305)$. Dengan cara ini cenderung diuraikan bahwa hal-hal dalam jajak pendapat itu substansial

\section{Uji Reliabilitas}

Digunakan untuk mengukur kuesioner yang merupakan poin dari variabel. Sebuah survei dianggap dapat diandalkan jika tanggapan responden terhadap pernyataan tersebut stabil. Semakin tinggi kualitas tak tergoyahkan suatu instrumen estimasi, semakin mantap instrumen estimasi tersebut. Sebuah variabel seharusnya dapat diandalkan jika memberikan nilai alpha $>0.60$.

Dalam pengujian penelitian, setiap faktor memiliki nilai Cronbach Alpha lebih dari 0,6. Ini menyiratkan bahwa semua faktor dalam pemeriksaan ini seharusnya solid untuk estimasi dan eksplorasi berikutnya

\subsection{Uji Statistik}

\section{Uji Signifikansi Parsial (Uji t)}

Uji t (parsial) bertujuan untuk mengetahui besarnya pengaruh masing-masing variabel independen terhadap variabel dependen uji t dibilang signifikan apabila kurang dari 0,05.

Hasil putput yang didapat pada tabel diatas yakni variabel intrinsic religiosity memiliki pengaruh positif dan kritis dengan nilai besar sebesar 0,001 yang menunjukkan bahwa tingkat religius konsumen mempengaruhi kesadaran halal dalam pemilihan makanan. Ini menyiratkan bahwa religius yang melekat pada individu akan membangun kesadaran barang halal.

Sedangkan variabel informasi barang halal berpengaruh positif dan immateriil dengan konsekuensi sebesar 0,933 , hal ini berimplikasi bahwa informasi barang halal berpengaruh terhadap pengaturan perhatian seseorang terhadap barang halal.

Variabel kehalalan barang berpengaruh positif dan kritis dengan nilai sangat besar sebesar 0,000 . Artinya seseorang yang memiliki kesadaran akan barang halal akan membangun niatnya untuk membeli barang halal. 


\section{Uji Signifikansi Simultan (Uji F)}

\section{Tabel 4.3.2 Uji F}

\section{ANOVA $^{\mathrm{a}}$}

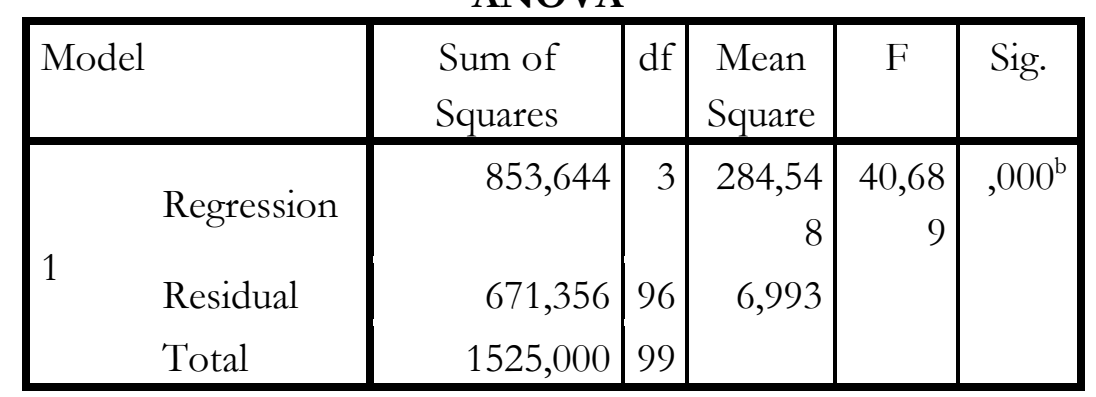

Hasil uji F pada penelitian ini memiliki nilai koefisiensi sebesar 40,689 dengan nilai signifikansi sebesar $0,000<0,05$. Sehingga bisa dikatakan bahwa hasil uji $\mathrm{F}$ pada penelitian ini memiliki nilai koefisiensi sebesar 40,689 dengan nilai signifikansi sebesar 0,000 $<0,05$. Dapat disimpulkan bahwa variabel intrinsic religiosity (X1), pengetahuan produk halal (X2) dan halal product awareness $(Z)$ secara simultan mempunyai pengaruh positif dan signifikan terhadap niat membeli produk halal

\section{Uji $\mathbf{R}^{2}$}

Tabel 4.3.3 Uji R

Model Summary ${ }^{\mathrm{b}}$

\begin{tabular}{|l|r|r|r|r|}
\hline Model & \multicolumn{1}{|c|}{$\mathrm{R}$} & R Square & \multicolumn{1}{|c|}{$\begin{array}{c}\text { Adjusted R } \\
\text { Square }\end{array}$} & $\begin{array}{l}\text { Std. Error of } \\
\text { the Estimate }\end{array}$ \\
\hline 1 &, $748^{\mathrm{a}}$ &, 560 &, 546 & 2,644 \\
\hline
\end{tabular}

Koefisien determinasi $\left(\mathrm{R}^{2}\right)$ sebesar 0,560. Ini menunjukkan bahwa kontribusi variabel independen menjelaskan atau mempengaruhi variabel dependen sebesar $56 \%$ sedangkan sisanya $(100 \%-56 \%=44 \%)$ dijelaskan oleh variabel yang lain diluar model

\subsection{Pembahasan}

Intrinsic Religiusitas memiliki dampak positif dan besar pada perhatian barang halal. Ini menyiratkan bahwa intrinsic religiusitas seseorang akan membangun keakraban dengan barang-barang halal.

Informasi tentang barang halal memiliki dampak positif dan besar terhadap kesadaran barang halal. Hal ini menyiratkan bahwa informasi tentang barang halal berdampak pada pengaturan kesadaran seseorang terhadap barang halal.

Kewaspadaan barang halal memiliki dampak positif dan besar terhadap harapan untuk membeli barang halal. Artinya orang yang punya perhatian ke barang halal dia memperluas tujuannya untuk membeli barang halal.

Intrinsic Religiusity memiliki dampak positif dan besar pada harapan untuk membeli barang halal. Ini menyiratkan bahwa seseorang yang memiliki ketegasan yang melekat akan lebih mampu untuk membeli barang-barang halal.

Informasi tentang barang halal memiliki dampak positif dan tidak relevan terhadap harapan untuk membeli barang halal. Karena ada berbagai elemen yang dapat memicu kondisi tidak adanya tujuan beli meskipun mereka benar-benar mengetahui data yang dibutuhkan dari suatu barang. Misalnya, ada produk substitusi yang lebih masuk akal dan sehat yang telah disusun secara syari'at sehingga tidak ada keragu-raguan untuk menghanguskannya. 
Intrinsic Religiusity memiliki dampak positif dan besar pada harapan untuk membeli barang halal melalui kesadaran barang halal sebagai perantara. Artinya perhatian terhadap barang halal punyai peran yang signifikan sebagai variabel perantara karena setiap pengembangan dalam keketatan bawaan harus memiliki pilihan untuk membangun kesadaran barang halal, kemudian, kemudian setelah kesadaran barang halal berkembang maka akan memperluas harapan untuk membeli. barang halal.

Informasi tentang barang halal memiliki dampak positif dan kritis terhadap tujuan pembelian barang halal melalui kesadaran barang halal sebagai perantara. Artinya kehati-hatian barang halal punyai peran yang signifikan sebagai perantara karena informasi tentang barang halal memiliki pilihan untuk membangun kesadaran barang halal, kemudian, kemudian setelah kesadaran barang halal berkembang maka akan terbentuk kesadaran akan barang halal. harapan untuk membeli barang halal.

\section{Penutup}

Intrinsic religiosity memiliki dampak positif dan kritis pada keakraban dengan barang halal. Informasi barang halal berdampak positif dan kritis terhadap perhatian terhadap barang halal. Keakraban dengan barang halal memiliki dampak positif dan kritis pada tujuan untuk membeli barang halal. Ketegasan bawaan memiliki dampak positif dan besar pada tujuan untuk membeli barang halal. Informasi tentang barang halal memiliki dampak positif dan immaterial terhadap tujuan pembelian barang halal. Ketat yang melekat memiliki dampak positif dan kritis terhadap tujuan pembelian barang halal melalui perhatian pada barang halal sebagai variabel intervening. Informasi tentang barang halal memiliki dampak positif dan kritis terhadap tujuan pembelian barang halal melalui kesadaran barang halal sebagai variabel perantara.Ayam Roket di Salatiga dituntut untuk menjaga kualitas dan kehalalan setiap barang yang diiklankan. Untuk penawaran ekspansi tambahan dan mendapatkan kesan yang layak dari pembeli

\section{Daftar Pustaka}

Ambali, A. R., \& Bakar, A. N. (2014). People's Awareness on Halal Foods and Products: Potential Issues for Policy-makers. Procedia - Social and Behavioral Sciences, 121 (September 2012), 3-25. https://doi.org/10.1016/j.sbspro.2014.01.1104

Astuty, P., \& Umiyati, U. (2018). Inluence Of Religiosity Towards The Saving Interest At Islamic Banking With The Knowledge Of The People As Moderator Variable (Case Study on The People of South Tanggerang City). Ikonomika, 3(1), 1. https://doi.org/10.24042/febi.v3i1.2229

Awan, H. M., Siddiquei, A. N., \& Haider, Z. (2015). Factors affecting Halal purchase intention evidence from Pakistan's Halal food sector. Management Research Review, 38(6), 640-660. https://doi.org/10.1108/mrr-01-2014-0022

Fauzia, diah retno sufi, Pangestu, E., \& Bafadhal, A. S. (2019). Pengaruh religiusitas, sertifikasi halal, bahan produk terhadap minat beli dan keputusan pembelian. Jurnal Administrasi Bisnis (JAB), 66(1), 37-46.

Fridayanti, F. (2016). Religiusitas, Spiritualitas Dalam Kajian Psikologi Dan Urgensi Perumusan Religiusitas Islam. Psympatbic: Jurnal Ilmiah Psikologi, 2(2), 199-208. https://doi.org/10.15575/psy.v2i2.460

Hwang, Y. (2015). Does Opinion Leadership Increase the Followers on Twitter. International Journal of Social Science and Humanity, 5(3), 258-264. https://doi.org/10.7763/ijssh.2015.v5.464

Muktadir-Al-Mukit, D., \& Keyamoni, T. J. (2019). Corporate Governance and Earnings 
Management Practices among Listed Firms: A Study on Post Stock Market Crisis Period in Bangladesh. Journal of Asian Business Strategy, 9(1), 1-9. https://doi.org/10.18488/journal.1006.2019.91.1.9

Selatan, J. R. (2018). The Role of Religiosity, Halal Awareness, Halal Certification, and Food Ingredients on In Search for Islamic Macroprudential Policy Purchase Intention of Halal Food in Indonesia: The Case of Financing to V alue (FTV) and Property Financing In Search . 0274.

Syafrida, S., \& Hartati, R. (2019). Kewajiban Sertifikat Halal Untuk Produk Impor di Indonesia. SALAM: Jurnal Sosial Dan Budaya Syar-I, 6(4), 363-376. https://doi.org/10.15408/sjsbs.v6i4.13718

Yousaf, S., \& Malik, M. S. (2013). Evaluating the influences of religiosity and product involvement level on the consumers. Journal of Islamic Marketing, 4(2), 163-186. https://doi.org/10.1108/17590831311329296 